\title{
PENDAMPINGAN PENATAAN PAMERAN PRODUK FURNITURE STUDI KASUS: PENGUSAHA MEBEL, KLENDER, JAKARTA
}

\author{
Maitri W. Mutiara ${ }^{1}$, Augustina Ika W. ${ }^{2}$, Edy Chandra $^{3}$ dan Eddy S. Marizar ${ }^{4}$ \\ ${ }^{1}$ Desain Interior, Universitas Tarumanagara \\ Email: maitrim@fsrd.untar.ac.id \\ 2 Desain Interior, Universitas Tarumanagara \\ Email: augustinaw@fsrd.untar.ac.id \\ ${ }^{3}$ Desain Komunikasi Visual, Universitas Tarumanagara \\ Email: edyc@fsrd.untar.ac.id \\ ${ }^{3} 4$ Desain Interior, Universitas Tarumanagara \\ Email: eddys@fsrd.untar.ac.id
}

\begin{abstract}
ABSTRAK
Dalam persaingan dengan industri, ada beberapa hal berkaitan dengan promosi yang dapat dilakukan agar produk yang ditawarkan dapat diminati dan dibeli. Koperasi Industri kayu dan Mebel di Kawasan Klender merupakan tempat berkumpulnya Usaha Kecil Menengah produk kayu dan mebel sejak tahun 1950an. Namun sejak tahun 1970an sampai saat ini belum mengalami perubahan yang signifikan sesuai dengan kemajuan jaman. Selain pola pikir, proses produksi, serta teknologi yang lumayan tertinggal, juga pengetahuan mengenai model promosi di jaman modern ini. Tim dari Fakultas Seni Rupa dan Desain, Universitas Tarumanagara menyelenggarakan pelatihan dengan materi manajemen bisnis industri mebel dan pelatihan berkaitan dengan promosi produk kayu dan mebel. Pelatihan promosi khususnya pada Penataan Pameran produk Kayu dan Mebel. Penataan pameran tidak terlepas dari keindahan secara visual dan bagaimana tatanan tersebut mempengaruhi penggunanya secara psikologis. Pertimbangan-pertimbangan tersebut dapat menambah daya tarik dan menjadi nilai lebih bagi produk kayu dan mebel yang ditata dengan prinsip-prinsip desain. Dengan demikian diharapkan dapat meningkatkan minat pembeli dan pada akhirnya akan meningkatkan angka penjualan. Pelaksanaan pengabdian kepada masyarakat di koperasi ini dilakukan dengan cara memberikan pelatihan dan pendampingan dalam penataan produk. Hasilnya para peserta mulai mengubah tata produk. Produk tidak hanya dikumpulkan di area yang sama, tapi juga ditata dan ditampilkan dengan lebih estetik dan memiliki konsep tertentu.
\end{abstract}

Kata kunci: tata pameran, produk kayu dan mebel, daya tarik

\section{PENDAHULUAN}

Ibukota Jakarta sebagai pusat pemerintahan sekaligus pusat ekonomi negara Indonesia tidak terlepas dari alternatif pilihan pariwisata baik bagi wisatawan manacanegara juga wisatawan lokal. Lokasi pariwisata terkenal di Jakarta adalah Monumen Nasional dan Museum-museum disekitar Jakarta. Namun juga terdapat pusat perbelanjaan pakaian dan kain dengan harga terjangkau yakni Tanah Abang, dan pusat cinderamata di kawasan Kota Tua. Terdapat satu kawasan kerajinan industri dan pusat belanja mebel kayu khas Betawi yang sudah ada sejak tahun 1950. Namun menurut pengamatan para pakar bisnis dan pakar mebel, proses produksi maupun promosi mebel kayu di kawasan Klender tidak banyak mengalami perubahan sejak tahun 1970an. 


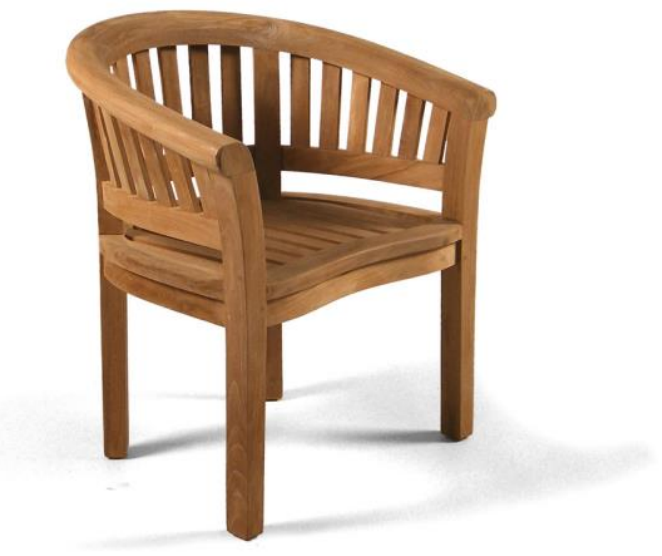

Gambar 1. Salah satu contoh gaya desain khas Jakarta pada produk mebel bangku yang banyak dapat kita temukan di kawasan Klender- Jakarta Timur. Dikenal dengan kursi Betawi.

Pada sebagian pengusaha yang merupakan Usaha Kecil Menengah (UKM), masih menggunakan produksi dan pemasaran dengan cara-cara konvensional atau cara lama dan tidak memperhatikan pentingnya promosi di era milenial ini. Dengan diaktifkannya perjanjian Masyarakat Ekonomi ASEAN (MEA) di tahun 2015, dimana Indonesia tergabung didalamnya, membuka peluang positif maupun negatif bagi bangsa Indonesia. Peluang positif karena artinya untuk memajukan perekonomian akan lebih terbuka. Peluang negatif karena Indonesia masih terlambat di bidang teknologi. Bahkan MEA dianggap menakutkan bagi para produsen lokal. Begitu juga bagi para produsen mebel di kawasan Klender. Untuk mengatasi hal tersebut, diperlukan pemikiran yang dapat memperbaiki metode bagi para pelaku UKM. Baik dari pola pikir, proses produksi, hingga membantu dalam perencanaan promosi bagi para pelaku UKM tersebut. Dalam melaksanakan Pengabdian pada Masyarakat sebagai salah satu bentuk dari pelaksanaan Tri Dharma Perguruan Tinggi, maka para akademisi dari Fakultas Seni Rupa dan Desain Universitas Tarumanagara pada kegiatan ini berfokus untuk membantu di kegiatan Promosi. Salah satunya adalah dengan pendampingan pada penataan pameran produk furniture. Kegiatan ini dilakukan di Koperasi Usaha Kecil Menengah Industri Mebel Kayu Klender. Dengan tujuan untuk membuka persepsi, pemikiran, dan motivasi para pengrajin mebel di Klender Jakarta Timur agar dapat berkembang dan bersaing dalam bisnis wisata belanja khas Kota Jakarta, terutama dalam penataan mebel sebagai tampilan visual. Tujuan dari pameran mebel itu sendiri adalah untuk meningkatkan minat pembeli, angka penjualan dan tidak terlepas dari mendapatkan keuntungan, dengan menambahkan nilai produk dalam promosi.

\section{METODE PELAKSANAAN PKM}

Pelaksanaan Pengabdian Masyarakat ini adalah dengan memberikan workshop dan demosntrasi selama 2 (dua) hari. Pada hari pertama adalah memberikan pemahaman umum tentang pameran Mebel dan cara untuk meningkatkan daya tarik bagi calon pembeli. Sebelum melakukan kegiatan workshop ini, tim terlebih dahulu melakukan beberapa persiapan, yakni: pertama, melakukan survey lapangan, mencari tahu permasalahan yang dihadapi oleh UKM. Kedua, mengumpulkan dan menyiapkan materi berkaitan dengan tata display dan pameran produk mebel. Ketiga, pembelian asesoris yang akan dipakai pada saat workshop.

Beberapa buku terkait display pameran furnitur dikumpulkan sebagai referensi, misalnya buku Basics Interior Design 02: Exhibition Design (by Pam Locker, 2010) dan Furniture For Interior Design (by Sam Booth and Drew Plunkett, 2014). Namun demikian, buku-buku tersebut 
menggunakan bahasa yang kemungkinan akan sulit dipahami oleh orang kebanyakan. Oleh karena itu dalam penyusunan materi presentasi tetap harus diolah kembali dengan bahasa dan metode yang mudah dipahami. Penyusunan materi presentasi display pameran juga menyesuaikan dengan materi presentasi manajemen bisnis yang menjadi satu rangkaian dalam kegiatan abdimas ini.

Materi presentasi secara garis besar dibagi menjadi 3 bagian, yaitu :

1. Pemahaman umum tentang Pameran Mebel

2. Cara meningkatkan minat pembeli

3. Contoh aksesoris

Penjelasan:

1. Pemahaman umum tentang pameran mebel

Pada bagian ini perlu disampaikan tujuan dari pameran mebel, adalah untuk meningkatkan minat pembeli sehingga menambah jumlah penjualan dan pada akhirnya mendatangkan keuntungan.

Dengan penekanan demikian, diharapkan peserta workshop dapat memahami urgensi penataan pameran mebel untuk keuntungan bisnis masing-masing UKM.

2. Cara meningkatkan minat pembeli

Dengan menyesuaikan materi pelatihan manajemen bisnis, maka pada presentasi ini perlu ditekankan bahwa bentuk pameran furnitur harus mengikuti perkembangan jaman. Sehingga dapat dilihat bahwa kecenderungan pameran furnitur saat ini adalah sebagai berikut:

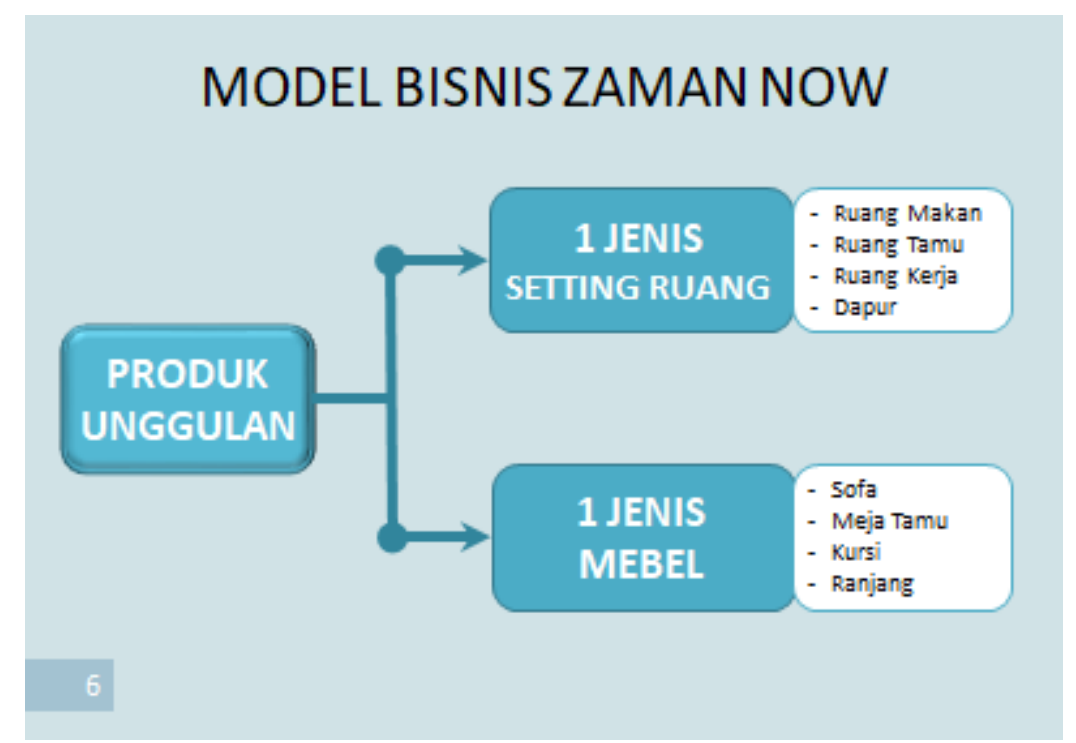

Gambar 2. Model Bisnis Zaman Now (sumber: Augustina Ika, 2018)

Pada dasarnya untuk mendapatkan perhatian pengunjung pameran, ada 2 (dua) metode yang dapat diterapkan. Metode pertama adalah dengan menghadirkan suasana penataan ruang tertentu sehingga pengunjung memiliki gambaran penerapannya di rumah atau kantor mereka. 


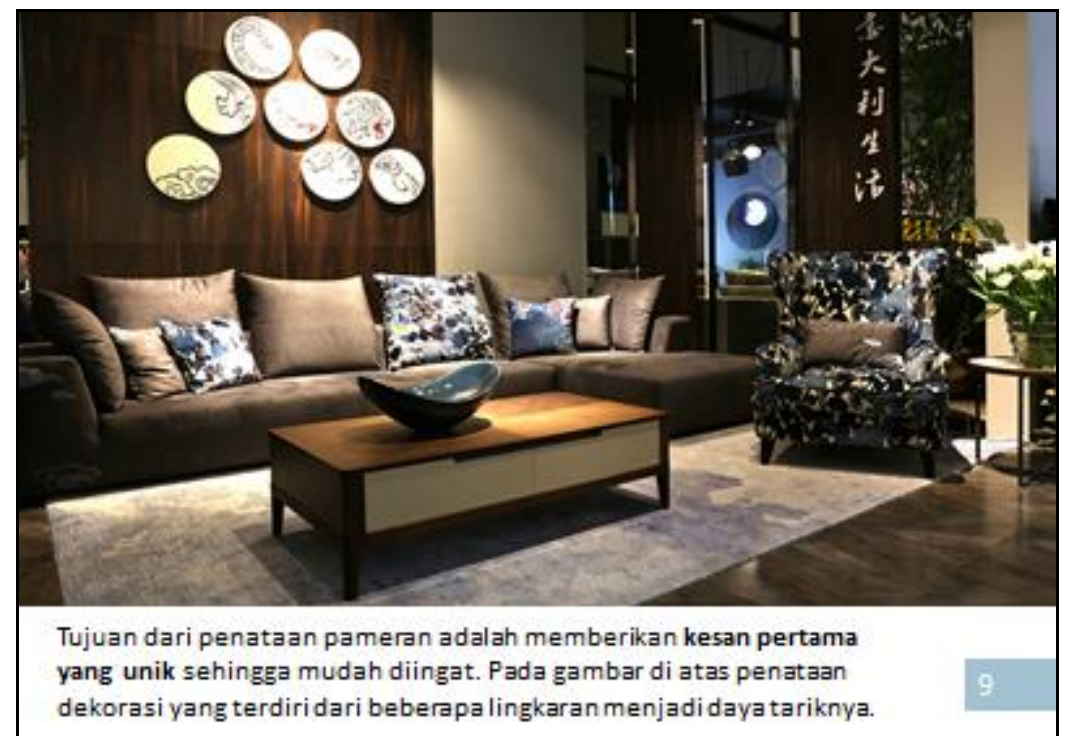

Gambar 3. Suasana Ruang (Sumber: Google, 2018)

Metode kedua adalah untuk mengekspos desain furnitur dengan cara menempatkan furnitur pada pedestal layaknya karya seni. Metode ini biasanya digunakan oleh para desainer furnitur maupun merek furnitur tertentu untuk memperkenalkan karya barunya ke khalayak umum.

Masing-masing metode memiliki kelebihan dan kekurangannya tersendiri. Dengan memberikan pemahaman dengan disesuaikan kondisi yang dialami oleh para peserta pelatihan, diharapkan seluruh peserta dapat memperbaiki sistem display pameran furnitur masing-masing di Gedung Pusat Promosi Industri Kayu dan Mebel.

\begin{tabular}{|l|l|}
\hline \multicolumn{2}{|c|}{ PERBANDINGAN } \\
\hline $\begin{array}{l}\text { GAMBARAN } \\
\text { PENATAAN }\end{array}$ & MENONIOLKAN MEBEL. \\
\hline $\begin{array}{l}\text { Perlu aksesoris } \\
\text { (aksesoris jugadijual) } \\
\text { Lebih realistik, } \\
\text { seperti penataan } \\
\text { sesungguhnya }\end{array}$ & Perlu pedestal atau panggung \\
$\begin{array}{l}\text { Bermacam-macam jenis mebel } \\
\text { (satu setting) } \\
\begin{array}{l}\text { Cocok untuk koleksi mebel } \\
\text { lama }\end{array}\end{array}$ & $\begin{array}{l}\text { Biasanya satu jenis mebel } \\
\text { (kalau beda-beda jadi berantakan) }\end{array}$ \\
\hline
\end{tabular}

Gambar 4. Perbandingan Pameran Mebel (penyusun: Augustina Ika, 2018) 


\section{Contoh aksesoris}

Sebagaimana disebutkan sebelumnya bahwa fungsi aksesoris adalah untuk menghidupkan suasana ruang. Kendala yang mungkin terjadi pada pengadaan aksesoris adalah, peserta tidak memiliki kesiapan aksesoris yang sesuai dengan setting yang ingin diterapkan oleh masingmasing unit UKM, sehingga dalam presentasi ini ditunjukkan beberapa contoh aksesoris yang terbuat dari kayu. Diharapkan setiap peserta memiliki rencana untuk memproduksi aksesoris sendiri, selain untuk memperkuat suasana setting interior, aksesoris tersebut juga untuk dijual sebagai komoditi mereka.

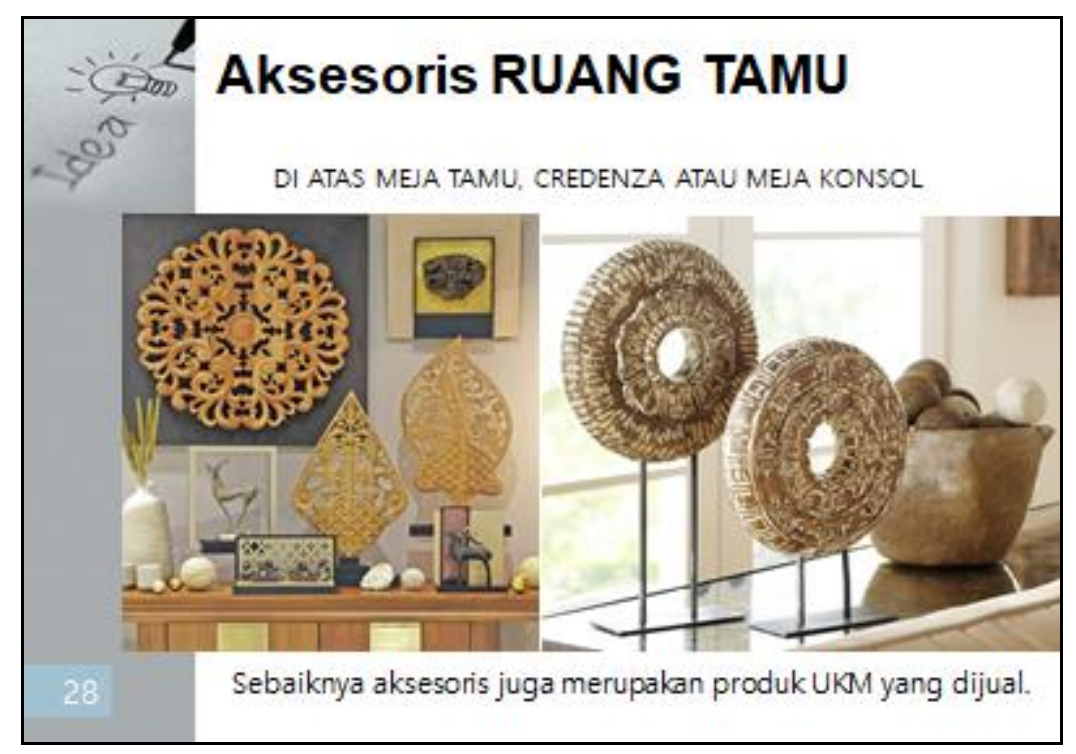

Gambar 5. Aksesoris pada penataan pameran Mebel (penyusun: Augustina Ika, 2018)

Selanjutnya materi presentasi tersebut akan dijadikan modul pelatihan yang dapat dibagikan kepada setiap peserta pelatihan, juga untuk dokumentasi Koperasi Mebel sehingga dapat diteruskan kepada UKM lain yang belum berkesempatan untuk mengikuti pelatihan.

\section{HASIL DAN PEMBAHASAN}

Persiapan workshop dilakukan seminggu sebelum kegiatan dilaksanakan. Persiapan tersebut meliputi kegiatan penyusunan materi presentasi, pemilihan mebel yang akan digunakan, termasuk pembelian aksesoris-aksesoris yang akan digunakan pada praktek workshop display pameran. Fungsi aksesoris pada sebuah pameran interior adalah untuk memperkuat konsep setting ruang interior tertentu, sehingga suasana ruang menjadi lebih nyata (hidup). Untuk pengadaan aksesoris setting interior, dipilih 2 (dua) jenis setting ruang yang akan dijadikan contoh pada praktek workshop pameran furnitur di hari kedua. Kedua setting ruang yang dipilih adalah setting ruang tamu (ruang duduk) dan setting ruang makan.

Hasil pelaksanaan terpapar dalam pelaksanaan kegiatan berikut ini:

Presentasi hari pertama pada 23 Januari 2018 mendapatkan sambutan yang baik dari para peserta. Karena materi sudah disesuaikan dengan materi pelatihan manajemen bisnis, sehingga peserta melihat kesinambungan acara secara keseluruhan. 


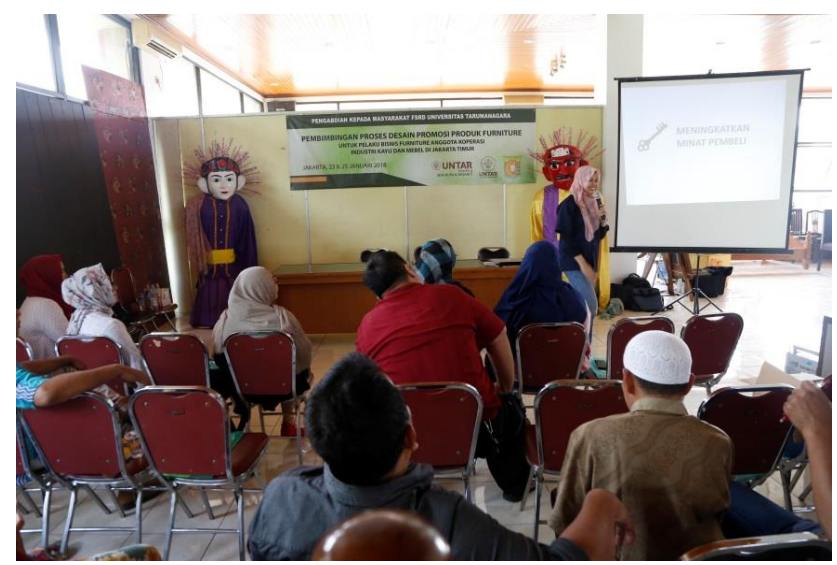

Gambar 6. Pelaksanaan Pembukaan Pelatihan (dok: Ruby C. 2018)

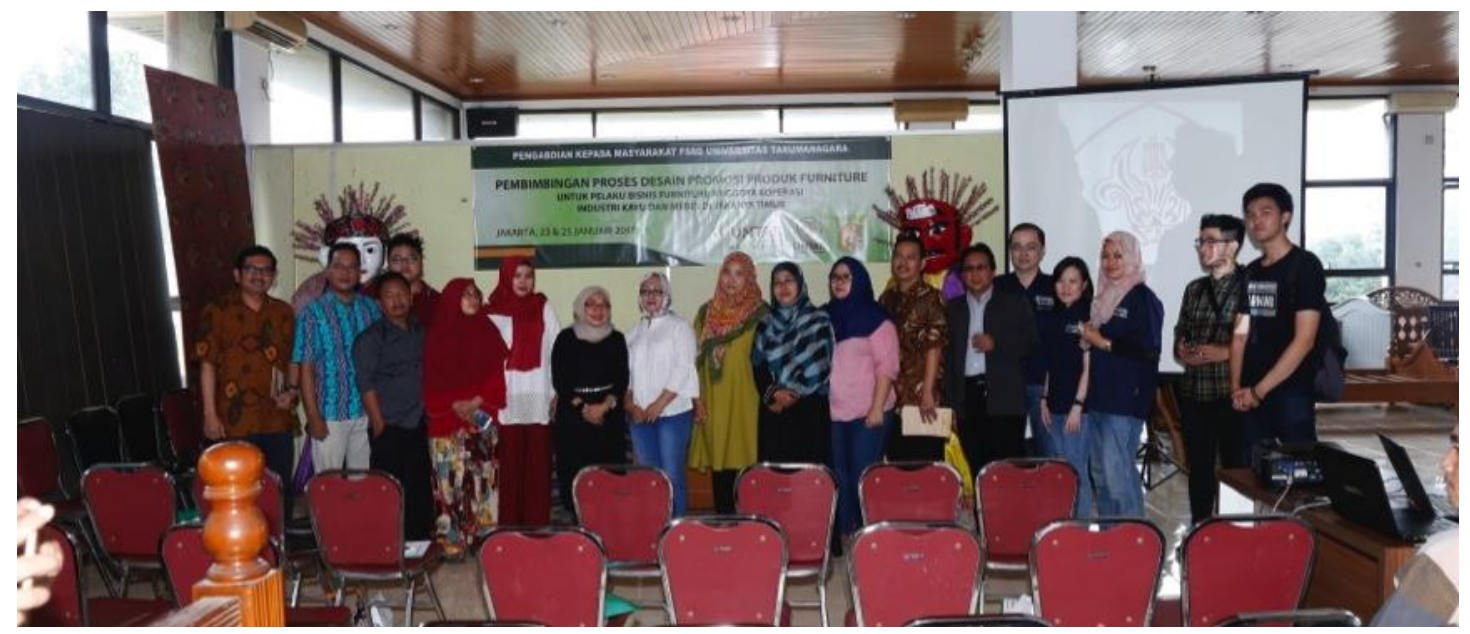

Gambar 7. Foto bersama narasumber dan instruktur, peserta, serta mahasiswa (dok. Ruby C., 2018)

Kegiatan hari pertama ditutup dengan meninjau display pameran yang dimiliki oleh para peserta workshop. Rencana awalnya adalah memilih satu display untuk ditata kembali sesuai dengan materi presentasi yang telah disampaikan. Namun setelah melihat display pameran yang tersedia di Gedung Promosi, ternyata tidak ada satupun display yang memiliki furnitur lengkap untuk satu jenis setting ruang interior tertentu. Semua display yang ada tidak mengindahkan penataan menurut kriteria yang diharapkan, sehingga diputuskan untuk memilih beberapa furnitur dari beberapa display yang berbeda. Furniture yang dipilih adalah yang memiliki konsep yang masih harmonis untuk ditempatkan dalam satu setting.

Kegiatan hari kedua pada 25 Januari 2018, memasuki kegiatan praktek dengan cara pendampingan untuk memberikan contoh penataan pameran yang dapat diikuti oleh peserta pelatihan. Untuk contoh penataan ini, tim Abdimas mendapatkan tempat yang cukup untuk digunakan sebagai 2 (dua) setting sebagaimana telah direncanakan sebelumnya. Yakni: setting ruang keluarga dan ruang makan. Furnitur yang telah dipilih pada hari pertama kemudian dipindahkan ke area praktek dengan bantuan mahasiswa dan peserta. 


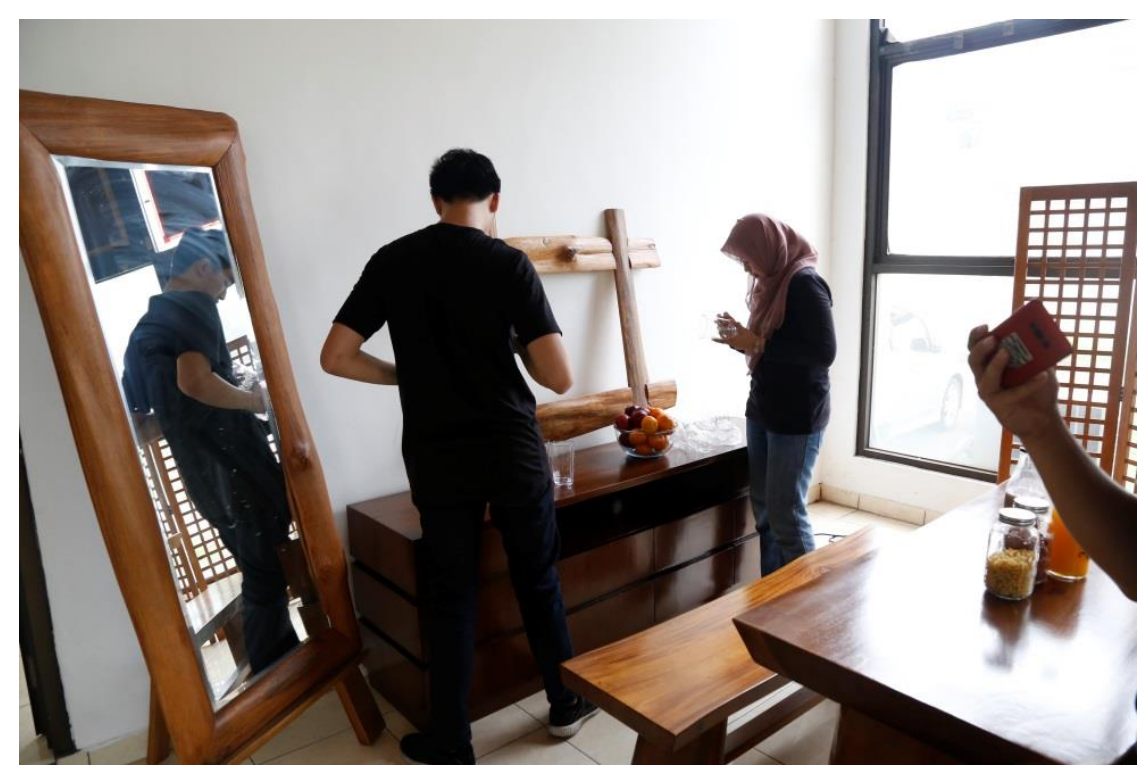

Gambar 8. Suasana Pelatihan Penaatan display Produk Mebel dan asesoris (dok. Ruby C., 2018)

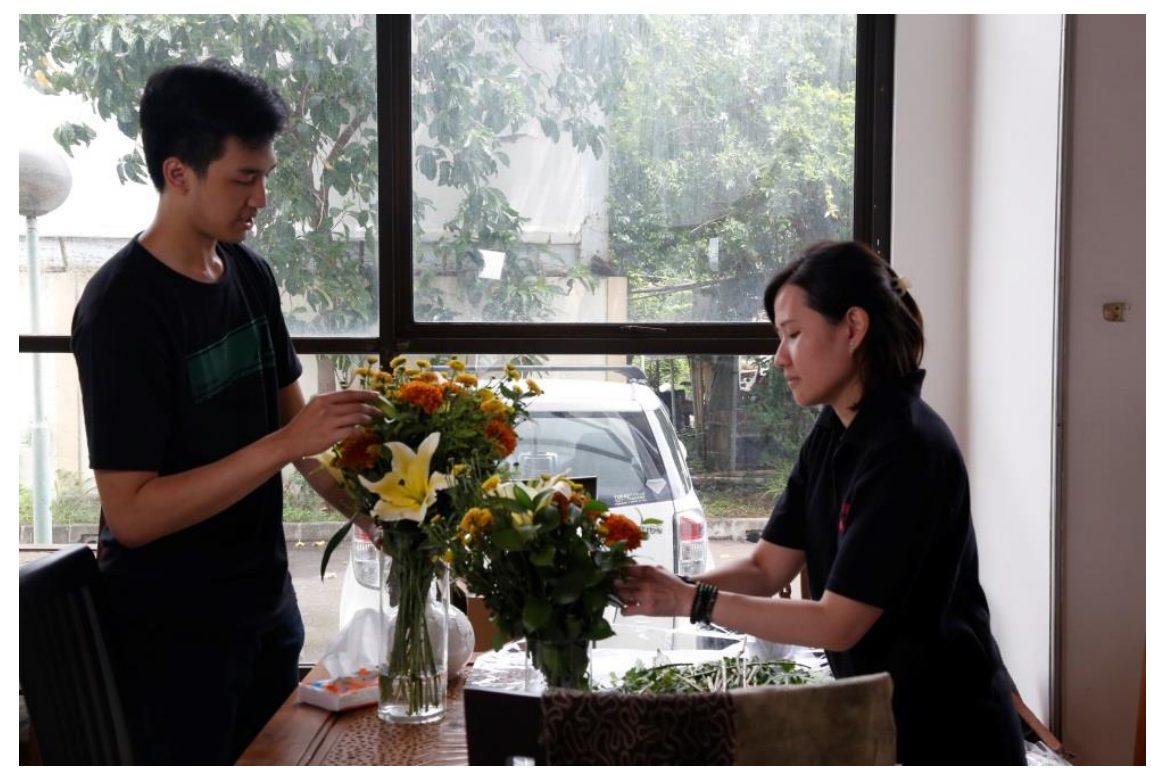

Gambar 9. Penataan Asesoris untuk Display Penataan Pameran Produk Mebel (dok. Ruby C., 2018)

Setelah contoh setting pameran selesai dikerjakan, peserta diberikan penjelasan mengenai cara menata pameran furnitur sesuai dengan materi presentasi. Maksud dari pengulangan materi adalah agar peserta mengingat kembali prinsip-prinsip yang harus diperhatikan dalam penataan pameran furnitur. Dengan contoh setting pameran yang dipersiapkan oleh tim Abdimas, peserta melihat langsung penerapan teori yang telah disampaikan sebelumnya. 


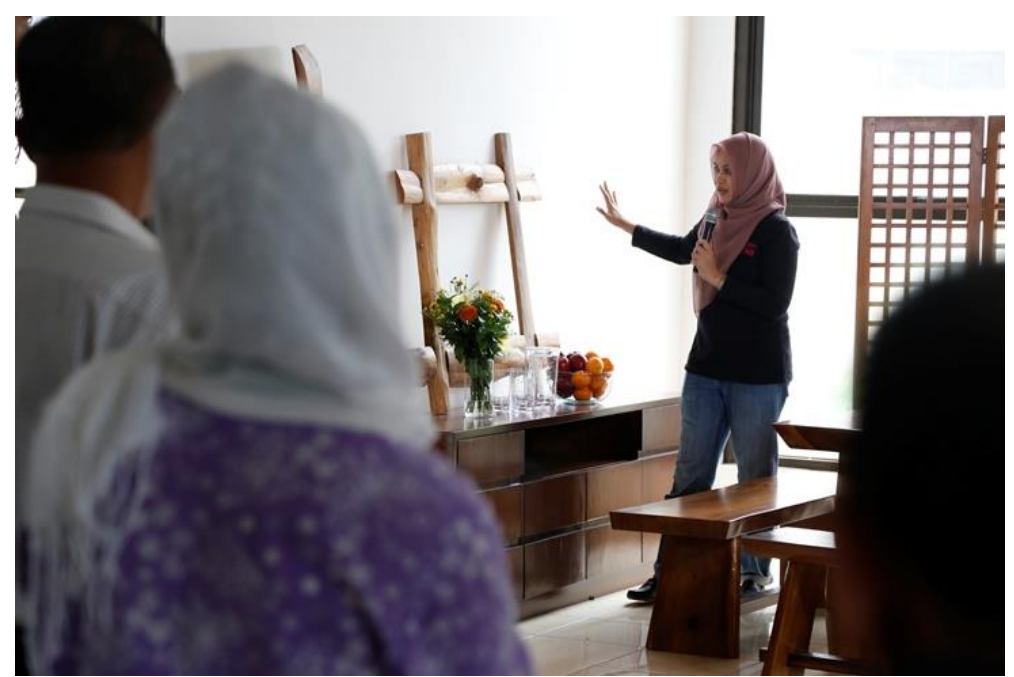

Gambar 10. Penjelasan Penataan Pameran (dok. Ruby C., 2018)

Tahapan ini juga merupakan bentuk pendekatan kepada peserta pelatihan untuk membuka wawasan sehingga diharapkan dapat memperbaiki penataan pameran masing-masing unit UKM yang ada di Gedung Pusat Promosi. Dengan melihat contoh setting pameran maka peserta dapat membandingkan suasana yang tercipta dari penataan yang memperhatikan konsep setting ruangan, serta penataan yang memaksakan sebanyak-banyaknya furnitur dalam satu tempat.

Kegiatan ini mendapatkan tanggapan positif dari peserta workshop, sehingga banyak yang mengambil foto contoh setting ruang pameran. Peserta juga antusias berswafoto maupun saling mengambil foto. Di akhir acara semua peserta berfoto bersama tim Abdimas dan pengurus Koperasi Mebel.

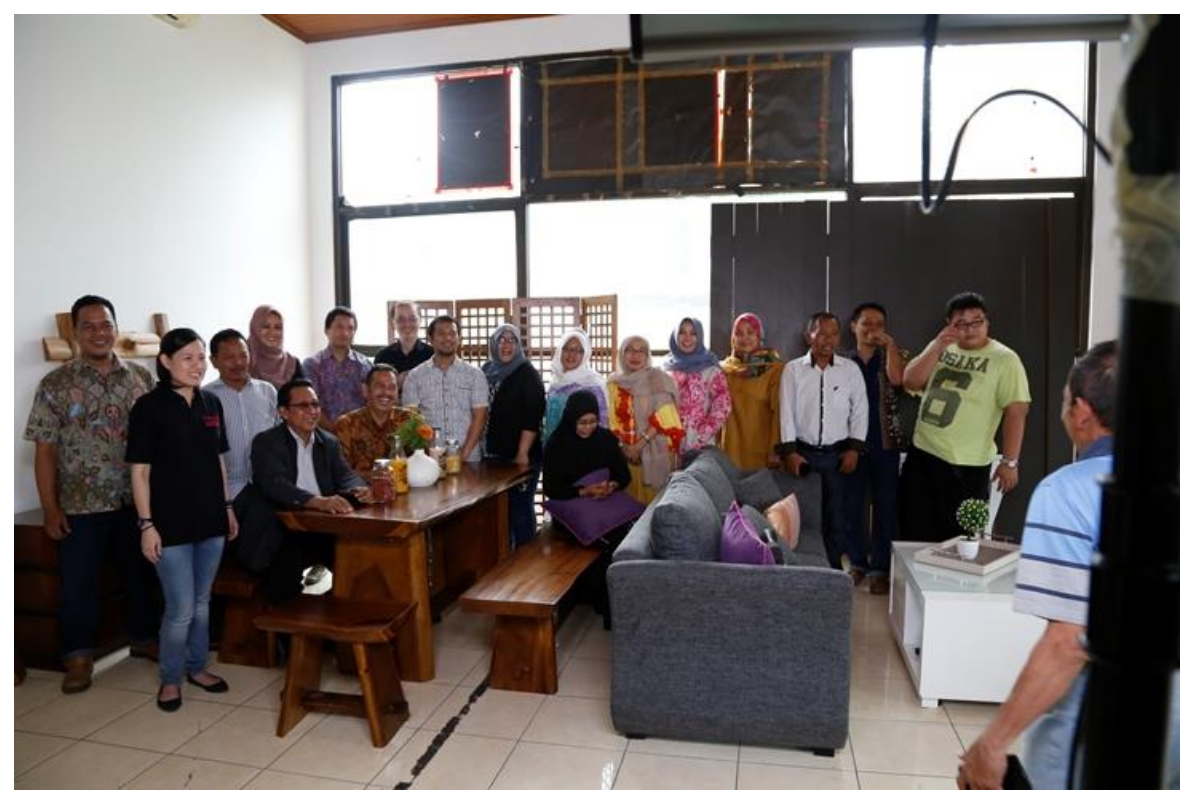

Gambar 11. Foto bersama peserta pelatihan. (dok. Ruby C., 2018)

Hasil Pelaksanaan kegiatan ini selain memberikan input posistif pada mitra di UKM juga membuka wawasan mengenai penataan pameran mebel. Hal ini berlanjut dengan workshop fotografi untuk media sosial. 


\section{KESIMPULAN DAN SARAN}

Hasil dari pelatihan dan pendampingan ini telah mendapat respon baik. Penataan pameran produk tidak lagi hanya bertumpukan pada masing-masing booth. Para pengusaha mulai memahami keinginan calon pembeli untuk dapat melihat tata produk yang lebih menggambarkan suasana uang tertentu, suasana ruang yang memiliki cerita dan konsep. Sehingga hal demikian akan meyakinkan dan memudahkan calon pembeli untuk memutuskan pembelian produk furniture.

\section{Ucapan Terima Kasih (Acknowledgement)}

Terima kasih kepada DPPM Untar yang telah mendukung secara materiil dan moril untuk berlangsungnya acara ini. Terima kasih kepada Bpk. Ade Firman selaku Kepala Koperasi Industri Kayu dan Mebel, Klender. Kepada Bapak Ruby Chryssandy yang telah membantu dalam pendokumentasian dan instruktur fotografi dalam kegiatan. Serta kepada Richard Santoso, dan Reynaldy Setiawan, mahasiswa yang juga menjadi asisten instruktur dalam kegiatan ini.

\section{REFERENSI}

Bell, Judith, (2017), Silent Selling: Best Practices and Effectives Strategies in Visual Merchandising. Fairchildbooks, English. ISBN: 9781609011536

Booth, S. \& Plunkett, D. (2014). Furniture For Interior Design. Laurence King Publishing Ltd. London. 6-7, 80-82.

Girsang, Manmpin, (2015), Meubelpreneur, Grasindo. Jakarta. ISBN: 9786022519188

Locker, Pam. (2010). Basics Interior Design 02: Exhibition Design. AVA Publishing SA. Switzerland. 16-17. 